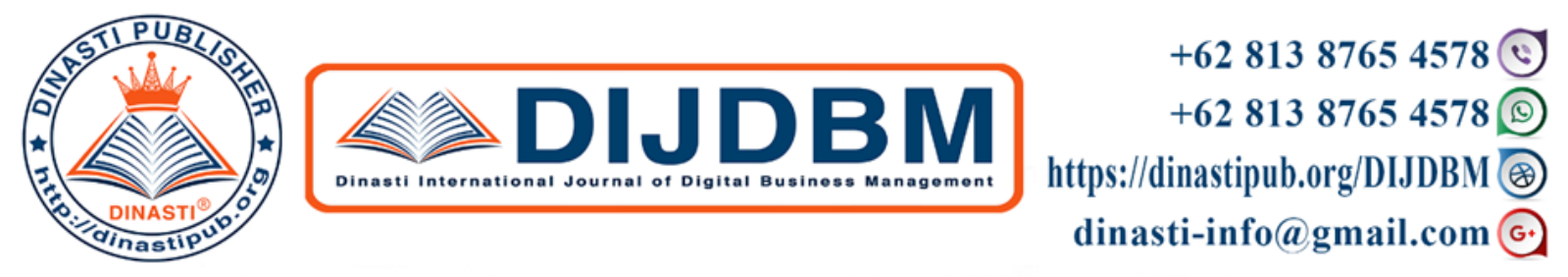

\title{
THE SKILLS OF JAMBI FIELD EXTENSION OFFICERS (FEO) IN WRITING RESEARCH PAPERS
}

\section{Denny Denmar ${ }^{1)}$, Siti Rahma Sari ${ }^{2)}$}

${ }^{1,2)}$ Faculty of Teacher Training and Education, Universitas Jambi, Jambi, Indonesia

\begin{tabular}{|c|c|}
\hline $\begin{array}{c}\text { ARTICLE INFORMATION } \\
\text { Received: } 27^{\text {th }} \text { June } 2020 \\
\text { Revised: } 20^{\text {th }} \text { July } 2020 \\
\text { Issued: } 22^{\text {th }} \text { August } 2020 \\
\text { Corresponding author: First } \\
\text { Author } \\
\text { E-mail: } \\
\text { dennydenmar101264@gmail.con }\end{array}$ & $\begin{array}{l}\text { ABSTRACT: This research aimed to show a close relationship } \\
\text { between: 1) The ability of verbal reasoning and the writing } \\
\text { scientific papers skill; } 2 \text { ) Understanding of word selection and the } \\
\text { writing scientific papers skill; } 3 \text { ) The ability to use cohesion } \\
\text { devices and the writing scientific papers skill; } 4 \text { ) The ability of } \\
\text { verbal reasoning, understanding of word selection, ability to use } \\
\text { cohesion devices together with the writing scientific papers skill } \\
\text { of Jambi FEO. This research used the method of survey with } \\
\text { correlational technique. The sample of this research was } 50 \\
\text { people who were the Civil Servants FEO, working at the Jambi } \\
\text { Provincial Extension Office in } 2019 \text {. The results showed a } \\
\text { significant and linear relationship between } 1 \text {. The verbal } \\
\text { reasoning ability and the writing scientific papers skill, shown by } \\
\text { the equation: } \hat{Y}=23,15+0,81 \mathrm{X}_{1} 2 \text {. Understanding of word } \\
\text { selection and the writing scientific papers skill, shown by the } \\
\text { equation: } \hat{\mathrm{Y}}=39,32+0,55 \mathrm{X}_{2} 3 \text {. The ability to use cohesion } \\
\text { devices and the writing scientific papers skill, shown by the } \\
\text { equation: } \hat{\mathrm{Y}}=40,02+0,57 \mathrm{X}_{3} 4 \text {. The verbal reasoning ability, } \\
\text { understanding of word selection, ability to use cohesion devices } \\
\text { together with the writing scientific papers skill, shown by the } \\
\text { equation: } \hat{Y}=21 \text {, } 09+0,421 \mathrm{X}_{1}+0,16 \mathrm{X}_{2}+0,27 \mathrm{X}_{3} \text {. The } \\
\text { multiple correlation coefficient was } \mathrm{R}_{\mathrm{y} 123}=0.85 \text {, and the } \\
\text { determination coefficient was } \mathrm{R}^{2}=0.72 \text {, which means that } 72 \% \\
\text { of variations in the scientific papers writing skill can be explained } \\
\text { by the verbal reasoning ability, understanding of word selection, } \\
\text { and the ability to use cohesion tools. } \\
\text { Keywords: Verbal reasoning ability, understanding of word } \\
\text { selection, ability to use cohesion devices, scientific papers } \\
\text { writing skills. }\end{array}$ \\
\hline
\end{tabular}

\section{INTRODUCTION}

Writing skills, especially in writing scientific papers, are the competency in which they, who are working in the academic world such as lecturers, researchers, and teachers, must have. However, scientific writing skills are not solely the demands of academics, and it must be acknowledged. In modern life, many other people, such as leaders of government or private organizations or institutions, are also required to have writing skills.

Field extension officers (FEO) must also have the skills in writing scientific papers. The importance of writing skills for FEO is something undebatable. In daily life, their work 
time is always involved with writing activities. They have to write papers, write reports, report on research activities, and ultimately arrange promotions. Writing is an inseparable part of FEO's scientific activities.

Such writing skills must still be owned and even developed when bearing the title FEO. As FEO, a person is required to be able to conduct research for the sake of importance, progress, and development of science and technology, or even for practical interests that are beneficial to life. The work challenge of the job work they are involved in is also often demanding the writing ability.

Writing skills will lead someone, including FEO, to become a scholar. In the information age and the rapid pace of the development of science and technology as it is now, writing skills will increasingly shift people's views about the image of one's intelligence. Benchmarks for someone's intelligence will be more determined by the papers they have written than their words. This can be understood because writing is the result of a complex cognitive work and has a broad range of readers, both judging from the dimensions of space and time.

More than just fulfilling daily tasks, FEO must try really hard to have language skills, including writing skills, because in turn they will become a non-formal teacher. FEO has an important role in learning activities in the education system, shown by its role as a party that must organize or manage other elements such as learning materials, the presentation system of learning materials, and the evaluation system for farmers.

The FEO writing skills are not as expected, in general, are not yet skilled in prioritizing Indonesian (Bahasa Indonesia). This becomes an obstacle in realizing a quality scientific paper. In this regard, the opinion which states that writing is essentially communicating what and how the author's mind, is noteworthy.

The aspects of error include spelling, diction, sentence, and paragraph organization. These errors are generally classified as intra-lingual errors, which are mainly caused by ignorance of rule restrictions, and imperfect application of rules.

In addition, the efforts to develop the skills in writing scientific papers need to be done. As it is emphasized, given writing has an important role in academic, social, and even personal life, the development of writing skills is a top priority in educational activities; through writing activities can encourage improvement of the high-level thinking skills of FEO.

Based on the above conditions, it is necessary to do research on the factors that enhance skills in writing scientific papers. Another consideration that encourages this research is that the research topic above has not yet been studied by many people. Some of the factors identified can improve the skills of writing scientific papers are: mastery of ideas to be written, ability of verbal reasoning, grammatical competence, understanding of word selection, ability to use cohesion tools, ability to apply improved Indonesian spelling, authors' understanding of prospective readers, and so on.

\section{THEORETICAL REVIEW}

\section{The Nature of the Skill of Writing Scientific Papers}

Writing, according to White and Arndt (1997: 3), is to arrange language into writing symbols. Writing is a process of thinking within the truth it has. In line with that opinion, Taimes (1983: 5-6) explains a number of components that must be present when writing, such as: (1) the purpose of writing; (2) relevance of content, clarity, originality, and logic; (3) understanding of future readers; (4) writing process (obtaining ideas, opaque writing, and revision); (5) grammar (verbal use, pronouns, articles, etc.); (6) use of sentence structure and style; (7) word selection; (8) writing techniques, and; (9) organizing ideas. 
Writing activity by Heaton (1998: 135) is a variety of skills needed to compose an essay, which includes: (1) grammatical skills, (2) content compaction, (3) sentence style skills, (4) mechanical skills, and (5) deciding skills.

Regarding writing as a complex cognitive skill, D'Angelo (1980: 19-20) argues that an author must be able to utilize the situation appropriately. Such situations that need to be considered are: (1) the authors' purpose, (2) the readers, and (3) opportunities (circumstances involving the occurrence of an event, time, place, and situation).

The purpose of writing is the readers' response expected by the authorss. Based on the authors' objectives, Levin (1987: 23-29) and Moeliono (1989: 124) provide essays in four categories, namely narration or narration, description, exposition or exposure, and argumentation or discussion.

In line with the above opinion, according to Sudjiman and Sugiono (1991: 1-3), scientific writing can be distinguished from: (1) books, (2) papers, (3) theses (for undergraduate programs), (4) theses (for graduate programs), and (5) dissertations (for postgraduate programs). The form of scientific papers intended in this research is a scientific paper (research paper, term-paper, or library paper). Scientific papers cover the focus and there are reliable facts, as well as opinions of experts to support views and analyze or explain (Frank, 1990: 275). While according to Arnaudet and Barret (1984: 188), it is a relatively long academic paper (about 1500 to 5000 words) and it is formal, in which students present a thesis and support the thesis with related data from a number of sources.

Based on the theoretical study above, it can be synthesized that the skill of writing scientific papers is the ability to compile a fact-based writing that can be accounted for, uses scientific writing methods, uses standard Indonesian, and is based on improved Indonesian spelling and the rules of scientific writing.

\section{The Nature of the Ability of Verbal Reasoning}

Reasoning is drawing conclusions from observations, facts, or hypotheses (Angelo, 1980: 241). According to Leahey and Haris (1980: 229), reasoning is the process of drawing logical conclusions based on existing facts or premises. According to Moeliono (1989: 124125), reasoning is the process of taking conclusions (inference from evidence), while according to Keraf (1992: 5), reasoning is a thought process that links facts to a conclusion. From the various opinions above, it is very clear that the reasoning is the process of thinking to draw a conclusion based on certain facts.

Suria Sumantri (1987: 42-43) said that logical thinking is thinking according to a certain logic. Meanwhile, according to Leonard (1967: 110-12) that logic is the science of reasoning consistently. That means that the science of reasoning seeks to find and state the rules according to the activity of thinking whose data is judged good or bad, right or wrong, or logical or illogical. The same thing stated by Copi (1978: 3) which states that logic is the study of methods and principles used to distinguish true reasoning from incorrect reasoning. Thus, it can be said that each form of reasoning has its own logic.

Based on the description above, the synthesis of verbal reasoning ability is the ability to think to draw conclusions that can be justified, both inductively and deductively, using language as the primary means as well as the ability to avoid wrong reasoning.

\section{The Nature of the Understanding of Word Selection}

A good essay is formed by choosing the right words and sentences, and must pay attention to, or consider the target readers (Heffernan and Lincoln, 1986: 170). In line with this opinion, according to McCrimmon (1986: 271), the selection of the right words is the best 
choice of words that allows authors to communicate meaning or ideas to readers. The selection of words is always made with reference to specific or certain sentences.

The use of an appropriate sentence is determined by the influence that the word has on the paragraph (McCrimmon, 1986: 269-270). Pustejovsky (1999: 1) states that to certain degrees, each word can be certain, even words that seem to have only one meaning can indicate multiple meanings in different contexts.

Furthermore, Keraf (1981: 73) suggests three main criteria related to the word selection, namely: (1) accuracy, (2) conformity/synonym, and (3) the use of language style. Other experts also say that the word selection is related to three main points, namely: (1) harmony, (2) accuracy and fidelity, and (3) the economics of language and cliché expressions (Moeliono, 1989: 173-179). Furthermore, Colderonello and Edwards (1986: 449) argue that four main points authors must pay attention to regarding the choice of words, namely: (1) the word selection should be in accordance with the writing formality level of formality, (2) the proper use of words, (3) avoid vague or unclear words; and (4) omit excessive words.

Based on the theoretical study above, it can be concluded that understanding of word selection is the ability to understand, choose, and use words or expressions appropriately, according to the ideas conveyed, according to the purpose of writing and target readers as well as their context.

\section{The Nature of the Ability to Use Cohesion Devices}

Essays contain a series of paragraphs that is also an integrated unit. The words after the initial and previous sections constitute the environment of the following sections which form the forecast essay (Halliday and hasan, 1992: 65). Correspondingly, Hariston (1986: 8) asserts that a coherent essay (having coherence) is an essay that has unity or cohesion. Based on the opinion of Halliday and Hasan and Hariston, it is clear that unity or coherence is the most prominent feature of an essay as a text.

Other experts argue that Cohesion is Using Reposition and Reference Words to Emphasize Key Ideals in Your Writing; (http://leo.stcloudstate.edu/style/cohesion.html, 1999). According to Gutwinski (1976: 26), cohesion is the relationship between sentences in a text. In line with that opinion, according to Nunan (1993: 21), cohesion refers to as a text forming device, which is a word or taste that allows authors or speakers to arrange relationships between sentences or between teachings, and which helps link sentences in a text. A similar opinion is expressed by Richards, Platt, and Weber (1985: 45) by using a more specific term, that cohesion is a grammatical and lexical relationship between elements in a text. The same opinion is also expressed by Hasan Alwi, et al. (1993: 481), which confirms that cohesion is the harmony of the relationship between one element and the other elements in the discourse, thus, creating a slick or coherent understanding.

Halliday and Hasan (1976: 5-6) describe completely the types of cohesion devices found in English. Broadly speaking there are five types, namely: (1) reference, (2) substitution, (3) ellipsis, (4) conjunction, and (5) lexical cohesion. Other experts put forward two relationships in the use of language, namely formal relations (reference to facts outside the language) (Cook, 1989: 15-21). Furthermore, Cook described the cohesion devices above: (1) verbal form, (2) alignment, (3) expression of reference, (3) repetition and lexical chain, (4) counseling, (5) disappearance, and (6) conjunctions. By Cook, cohesion devices can be distinguished from grammatical cohesion and lexical cohesion. Grammatical cohesion is distinguished by: (1) reference and (2) conjunction.

The cohesion device study that has been put forward by some of the experts above used English language data, and has been comprehensively carried out by several experts such as Sugono (1995), Sarnsuri (1987), and Alwi, et al. (1993). 
In his research, Sugono, et al. (1995, 1-2), focuses his attention on cohesion that refers to the subject, and the linkage between sentences in discourse as well as the linkage between clauses in sentences.

Samsuri (1987: 36) suggests the types of cohesion devices, namely: (1) cause-effect relationships, (2) repetition of words or phrases, (3) lexical replacement, (4) form substitution, (5) metaphors, and (6) relationships lexical.

Based on the theoretical study above, it can be synthesized that the ability to use cohesion devices is the authors' knowledge regarding tools that can form formal relationships between sentences in the text, and their ability to use these tools.

\section{The Relationship between the Understanding of Word Selection and the Skills in Writing Scientific Papers}

Writing is essentially a communication activity carried out by authors to readers or target readers. Readers or authors are required to have an adequate vocabulary. Vocabulary is an important element that shows one's language ability. However, ownership of vocabulary even in large numbers does not guarantee the success of the communication. The important thing that is required of writers to be related to the vocabulary correctly is that it must be in accordance with the ideas conveyed, the purpose of writing, readers, and the context.

The understanding of word selection allows authors to be able to distinguish precisely the nuances of meaning in accordance with the ideas to be conveyed, and find forms that fit the situation and the sense of value owned by readers or target readers, and the understanding of word selection from authors themselves in expressing their ideas in a right way, and avoid misperceptions from readers. The various points of thought presented above confirm that there are many links between the understanding of word selection and the writing skills.

Based on the description above, it is assumed that there is a positive relationship between the understanding of word selection and the skills in writing scientific papers.

\section{The Relationship between the Ability to Use Cohesion Devices and the Skills in Writing Scientific Papers}

One important characteristic of an essay is the wholeness or coherence. In a good essay, each sentence in a paragraph strengthens or supports the main idea of the paragraph, and is related to other sentences, both those that precede other sentences, and those that follow. The sentences are in harmony, and in logical order. Such logical bond is not only between sentences in paragraphs, but also between paragraphs with other paragraphs.

The authors' attempt to realize cohesiveness between sentences based on their compatibility with the reference frame depends very much on the ability to use cohesion devices. In other words, the knowledge and understanding of grammatical and lexical relationships, and the ability to apply them, are important factors for the creation of good or coherent discourses or essays.

The cohesion device can direct readers to the things that have been mentioned and those mentioned next. Meanwhile, with the conjunction cohesion tool, authors can arrange effective sentences, connect between sentences into a paragraph, and connect between paragraphs. Finally, authors can use various strategies to make the expression effective. The description above clearly shows that the ability to use cohesion devices can make essays effective.

Thus, it is assumed that there is a positive relationship between the ability to use cohesion devices and the skills in writing scientific papers. The Relationship between the Ability of Verbal Reasoning, the Understanding of Word Selection, and the Ability to Use Cohesion Devices, with the Skills in Writing Scientific Papers. 
Realizing a good scientific writing is required to have a number of reasoning abilities, adequate vocabulary selection, as well as understanding and applying it correctly, mastery of sentences, mastery of spelling and mechanical aspects, and abilities related to aspects of discourse included in the use of cohesion devices, etc.

These various abilities have important meanings for the process of composing essays. The ability of verbal reasoning, the understanding of word selection, and the ability to use cohesion tools, those are the main elements supporting writing skills. With the ability of verbal reasoning, authors organize their essays well. In addition, they can distinguish and determine things that include facts or not, general or personal facts, and facts of scientific value. Finally, with the ability to use cohesion devices, authors arrange interlocked paragraphs that so that a coherent discourse or text is realized.

From the description above, it is clear that good essays are the essays that need to be organized, have the right expression of ideas, and can achieve the desired goals.

Based on that, it can be assumed that there is a positive relationship between the ability of verbal reasoning, the understanding of word choice, and the ability to use cohesion devices, with the skills in writing scientific papers.

\section{Research Hypothesis}

First, there is a positive relationship between the ability of verbal reasoning and the skills in writing scientific papers.

Second, there is a positive relationship between the understanding of word selection and the skills in writing scientific papers.

Third, there is a positive relationship between the ability to use cohesion devices and the skills in writing scientific papers.

Fourth, there is a positive relationship between the ability of verbal reasoning, the understanding of word selection, and the ability to use cohesion devices, altogether with the skills in writing scientific papers.

\section{RESEARCH METHOD}

This research used the method of survey correlational technique which aimed to discover whether there was a relationship between the ability of verbal reasoning, the understanding of word selection, and the ability to use cohesion devices, with the skills in writing scientific papers, both individually and jointly.

To collect data on the skills in writing scientific papers, an instrument in the form of a composition test was used; while for the other three data instruments were used in the form of objective tests. Before they were used, a trial was conducted. From the trial, the reliability coefficients were obtained: (1) the instrument of the skills in writing scientific paper $=0.97$; (2) the instrument of the ability of verbal reasoning $=0.93$; (3) the instrument of the understanding of word selection $=0.90$; and (4) the instrument of the ability to use cohesion devices $=0.91$.

Before testing the hypothesis, a normality test of the data was performed using the estimated error formula (Y-Y) and homogeneity test through the Harriett test. The test results showed that the estimated error ( $\mathrm{Y}-\mathrm{Y})$ was normally distributed and the variance between $\mathrm{Y}$ groups was based on homogeneous $\mathrm{Xi}$.

Based on the data analysis, the following research findings were obtained:

First, there is a positive relationship between the ability of verbal reasoning $\left(\mathrm{X}_{1}\right)$ and the skills in writing scientific papers $(\mathrm{Y})$ with the regression equation $Y=23.15+0.81 X_{1}$; can be seen in Figure 1. 
Table 1. Analysis of Variance (ANAVA) for Test of Meaning and Linearity of Regression of Writing Scientific Papers Skills (Y) on Reasoning Ability $\left(\mathbf{X}_{1}\right)$.

\begin{tabular}{|l|c|r|r|r|r|r|}
\hline \multirow{2}{*}{ Varian Source } & \multirow{2}{*}{ Dk } & \multirow{2}{*}{ JK } & \multirow{2}{*}{ RJK } & \multirow{2}{*}{$\mathbf{F}_{\text {count }}$} & \multicolumn{2}{|c|}{$\mathbf{F}_{\text {table }}$} \\
\cline { 6 - 7 } & & & & $\boldsymbol{\alpha}=\mathbf{0 . 0 5}$ & $\boldsymbol{\alpha}=\mathbf{0 . 0 1}$ \\
\hline Total & 50 & 284424 & - & - & - & - \\
\hline Coefficient (a) & 1 & 280051.253 & - & - & - & - \\
Regression (b/a) & 1 & 2650.253 & 2650.253 & $73.85^{* *}$ & 4.04 & 7.19 \\
Rest & 48 & 1722.467 & 35.885 & & & - \\
\hline Match Tuna & 22 & 328.527 & 21.902 & $0.52^{\text {ns }}$ & 1.61 & 2.62 \\
Error & 12 & 1393.94 & 42.241 & - & - & - \\
\hline
\end{tabular}

Information:

$$
\begin{array}{ll}
\mathrm{JK} & =\text { Number of Squares } \\
\mathrm{dk} & =\text { Degree of Freedom } \\
\text { RJK } & =\text { Average Number of Squares } \\
* * & =\text { Significant Regression }\left(\mathrm{F}_{\mathrm{c}}=73.85>\mathrm{F}_{1}=7.19\right) \\
\mathrm{ns} & =\text { Linear regression }\left(\mathrm{F}_{\mathrm{c}}=0.52<\mathrm{F}_{1}=1.98\right)
\end{array}
$$

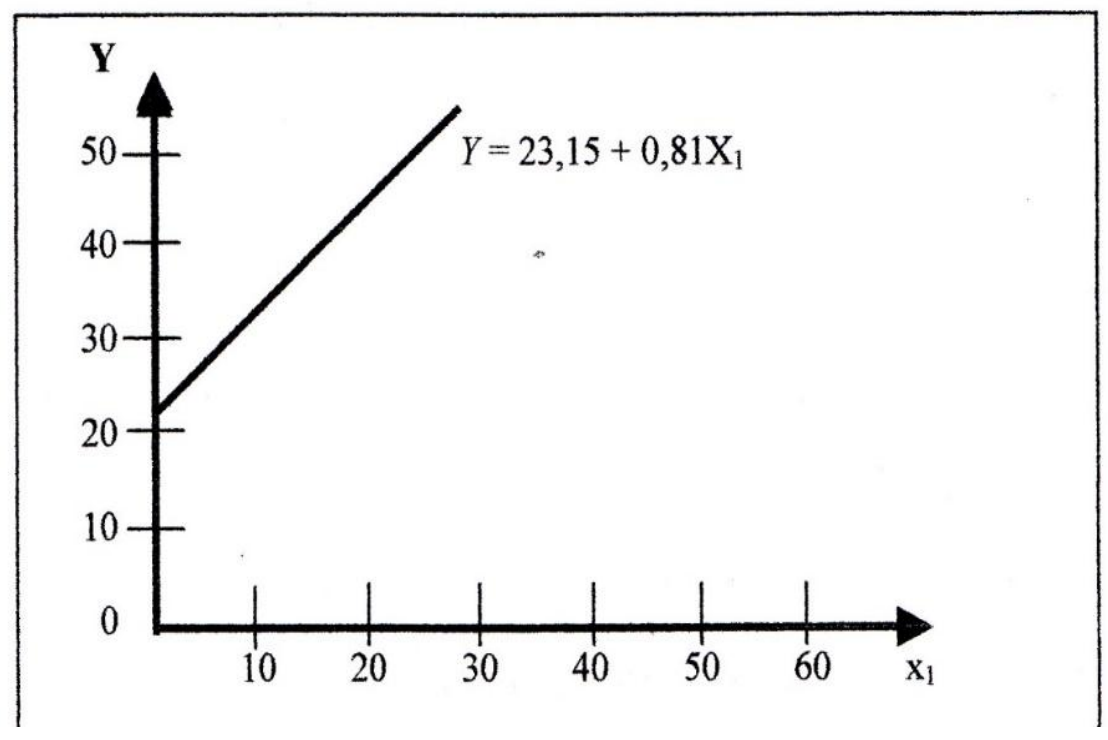

Figure 1. Regression Line Graph $Y=23.15+0.81 X_{1}$

The calculation results regarding the strength of the relationship between the components of verbal reasoning $\left(\mathrm{X}_{1}\right)$ and writing scientific papers skills $(\mathrm{Y})$ are shown by the correlation coefficient $r y 1=0.78$. This turned out to be very significant, as shown in Table 2 .

Determinant Coefficient $r_{y l}^{2}=0.606$, means that the variation of the writing scientific papers skills can be explained by the variation of reasoning ability by $60.6 \%$. Partial correlation coefficient $r_{y 1.23}=0.4$, tested by t-test, resulting $\mathrm{t}_{\text {count }}=3.37>\mathrm{t}_{\text {table }}=2.405 \alpha=$ 0.01 (very significant). In other words, the $\mathrm{X}_{1}$ variable is stably positive related to the $\mathrm{Y}$ variable. 
Table 2. List of $\mathbf{r}_{\mathbf{y} 1}$ Correlation Coefficient Significance Test

\begin{tabular}{|c|c|c|c|c|}
\hline $\begin{array}{c}\text { Correlation } \\
\text { Coefficient }\end{array}$ & $\begin{array}{c}\text { Degree of } \\
\text { Freedom }\end{array}$ & \multirow{2}{*}{ F $_{\text {count }}$} & \multicolumn{2}{|c|}{ F $_{\text {table }}$} \\
\cline { 4 - 5 } & 48 & $8.594 * *$ & $\mathbf{0 . 0 5}$ & $\mathbf{0 . 0 1}$ \\
\hline 0.78 & 48 & 1.675 & 2.405 \\
\hline
\end{tabular}

$* *=$ The correlation coefficient is very significant $\left(\mathrm{t}_{\text {count }}=8.594>\mathrm{t}_{\text {table }}=2.405\right)$

Second, there is a positive relationship between the word selection understanding $\left(\mathrm{X}_{2}\right)$ and the writing scientific papers skills $(\mathrm{Y})$ with the regression equation $7=39.32+0.55 \mathrm{X}_{2}$. This regression equation is very meaningful and linear (see Table 3), meaning that each increase in one unit of word selection understanding is followed by an increase in the value of writing scientific papers skills by 0.55 units with a constant of 39.32. The graph form of the regression equation can be seen in Figure 2.

Table 3. Analysis of Variance (ANAVA) for Test of Meaning and Linearity of Regression of Writing Scientific Papers Skills (Y) on Reasoning Ability $\left(\mathbf{X}_{2}\right)$.

\begin{tabular}{|l|c|r|r|r|r|r|}
\hline \multirow{2}{*}{ Varian Source } & \multirow{2}{*}{$\mathbf{d k}$} & \multicolumn{1}{|c|}{ JK } & \multirow{2}{*}{ RJK } & $\mathbf{F}_{\text {count }}$ & \multicolumn{2}{|c|}{ F $_{\text {table }}$} \\
\cline { 5 - 7 } & & & & & $\boldsymbol{\alpha}=\mathbf{0 . 0 5}$ & $\boldsymbol{\alpha}=\mathbf{0 . 0 1}$ \\
\hline Total & 50 & 284424 & - & - & - & - \\
\hline Coefficient (a) & 1 & 280051.28 & - & - & - & - \\
Regression (b/a) & 1 & 2095.517 & 2095.517 & $44.170^{* *}$ & 4.04 & 7.19 \\
Rest & 48 & 2277.203 & 47.442 & & & - \\
\hline Match Tuna & 11 & 603.028 & 54.028 & $1.28^{\text {ns }}$ & 2.05 & 2.75 \\
Error & 37 & 1674.175 & 42.927 & - & - & - \\
\hline
\end{tabular}

Information:

$\begin{array}{ll}\mathrm{JK} & =\text { Number of Squares } \\ \mathrm{dk} & =\text { Degree of Freedom } \\ \text { RJK } & =\text { Average Number of Squares, } \\ * * & =\text { Significant Regression }\left(\mathrm{F}_{\mathrm{c}}=44.170>\mathrm{F}_{1}=7.19\right) \\ \mathrm{ns} & =\text { Linear regression }\left(\mathrm{F}_{\mathrm{c}}=1.28<\mathrm{F}_{1}=2.05\right)\end{array}$




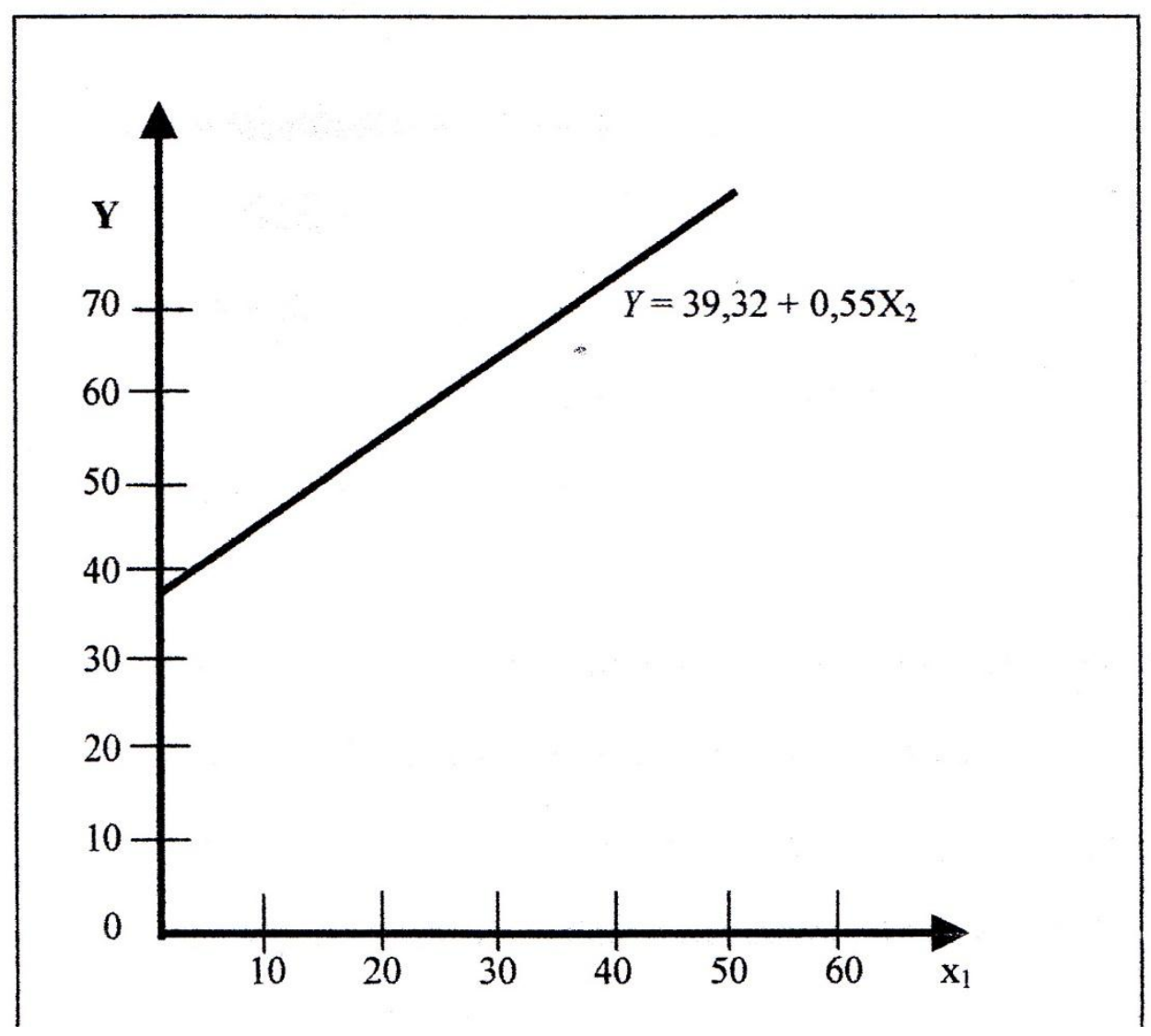

Figure 2. Regression Line Graph $Y=39.32+0.55 X_{2}$

The calculation of the strength of the relationship between the word selection understanding (X2) and the writing scientific papers skills (Y) is shown by the correlation coefficient $\mathrm{r}_{\mathrm{y} 2}=0.69$, which turned out to be very significant (see Table 4 ).

Table 4. List of $\mathbf{r}_{\mathbf{y} 2}$ Correlation Coefficient Significance Test

\begin{tabular}{|c|c|c|c|c|}
\hline \multirow{2}{*}{$\begin{array}{c}\text { Correlation } \\
\text { Coefficient }\end{array}$} & $\begin{array}{c}\text { Degree of } \\
\text { Freedom }\end{array}$ & \multirow{2}{*}{$\mathbf{F}_{\text {count }}$} & \multicolumn{2}{|c|}{ F $_{\text {table }}$} \\
\cline { 4 - 5 } & & & $\mathbf{0 . 0 5}$ & $\mathbf{0 . 0 1}$ \\
\hline 0.69 & 48 & $6.646^{* *}$ & 1.675 & 2.405 \\
\hline
\end{tabular}

$* *=$ The correlation coefficient is very significant $\left(\mathrm{t}_{\mathrm{count}}=6.646>\mathrm{t}_{\mathrm{table}}=2.405\right)$

Determinant coefficient $r_{\mathrm{y} 2}^{2}=0.479$, means that variations in the writing scientific papers skills can be explained by variations in the word selection understanding by $47.9 \%$. Partial correlation coefficient $r_{\mathrm{y} 2 \cdot 13}=0.26$, tested by $\mathrm{t}$-test, resulting in $\mathrm{t}_{\text {count }}=\mathrm{t}_{\text {table }} 1.675 \alpha=$ 0.01 (significant). In other words, the $\mathrm{X}_{2}$ variable is stably positive related to the $\mathrm{Y}$ variable. 
Third, there is a positive relationship between the ability to use cohesion devices $\left(\mathrm{X}_{2}\right)$ and the writing scientific papers skills $(\mathrm{Y})$ with a regression equation $7=40.02+0.57 \mathrm{X}_{1}$. The test for the significance of regression linearity can be seen in Table 5. The meaning of the regression equation is that each increase in one unit of the value of the ability to use cohesion devices is followed by an increase in the value of writing scientific papers skills by 0.57 units with a constant of 40.02. Figure 3 shows the graphic form of the regression equation.

The calculation results regarding the strength of the relationship between the ability to use cohesion devices $\left(\mathrm{X}_{3}\right)$ and the writing scientific papers skills $(\mathrm{Y})$ are shown by the correlation coefficient $\mathrm{ry}_{3}=0.75$. This correlation coefficient is very significant, as shown in Table 6.

Table 5. Analysis of Variance (ANAVA) for Test of Meaning and Linearity of Regression of Writing Scientific Papers Skills (Y) on the Ability to Use Cohesion Devices $\left(\mathrm{X}_{3}\right)$.

\begin{tabular}{|l|c|r|r|r|r|r|}
\hline \multirow{2}{*}{ Varian Source } & \multirow{2}{*}{$\mathbf{d k}$} & \multicolumn{1}{|c|}{ JK } & \multirow{2}{*}{ RJK } & $\mathbf{F}_{\text {count }}$ & \multicolumn{2}{|c|}{ F $_{\text {table }}$} \\
\cline { 5 - 7 } & & & & & $\boldsymbol{\alpha}=\mathbf{0 . 0 5}$ & $\boldsymbol{\alpha = 0 . 0 1}$ \\
\hline Total & 50 & 284424 & - & - & - & - \\
\hline Coefficient (a) & 1 & 280051.28 & - & - & - & - \\
Regression (b/a) & 1 & 2436.559 & 2436.559 & $60.406^{* *}$ & 4.04 & 7.19 \\
Rest & 48 & 1936.461 & 40.337 & & & - \\
\hline Match Tuna & 12 & 446.561 & 38.88 & $0.95^{\text {ns }}$ & 2.03 & 2.72 \\
Error & 36 & 1469.6 & 40.62 & - & - & - \\
\hline
\end{tabular}

Information:

$\begin{array}{ll}\mathrm{JK} & =\text { Number of Squares } \\ \mathrm{dk} & =\text { Degree of Freedom } \\ \text { RJK } & =\text { Average Number of Squares, } \\ * * & =\text { Significant Regression }\left(\mathrm{F}_{\mathrm{c}}=60.406>\mathrm{F}_{1}=7.19\right) \\ \mathrm{ns} & =\text { Linear regression }\left(\mathrm{F}_{\mathrm{c}}=0.95<\mathrm{F}_{1}=2.03\right)\end{array}$


Figure 3. Regression Line Graph $Y=40.02+0.57 X_{3}$

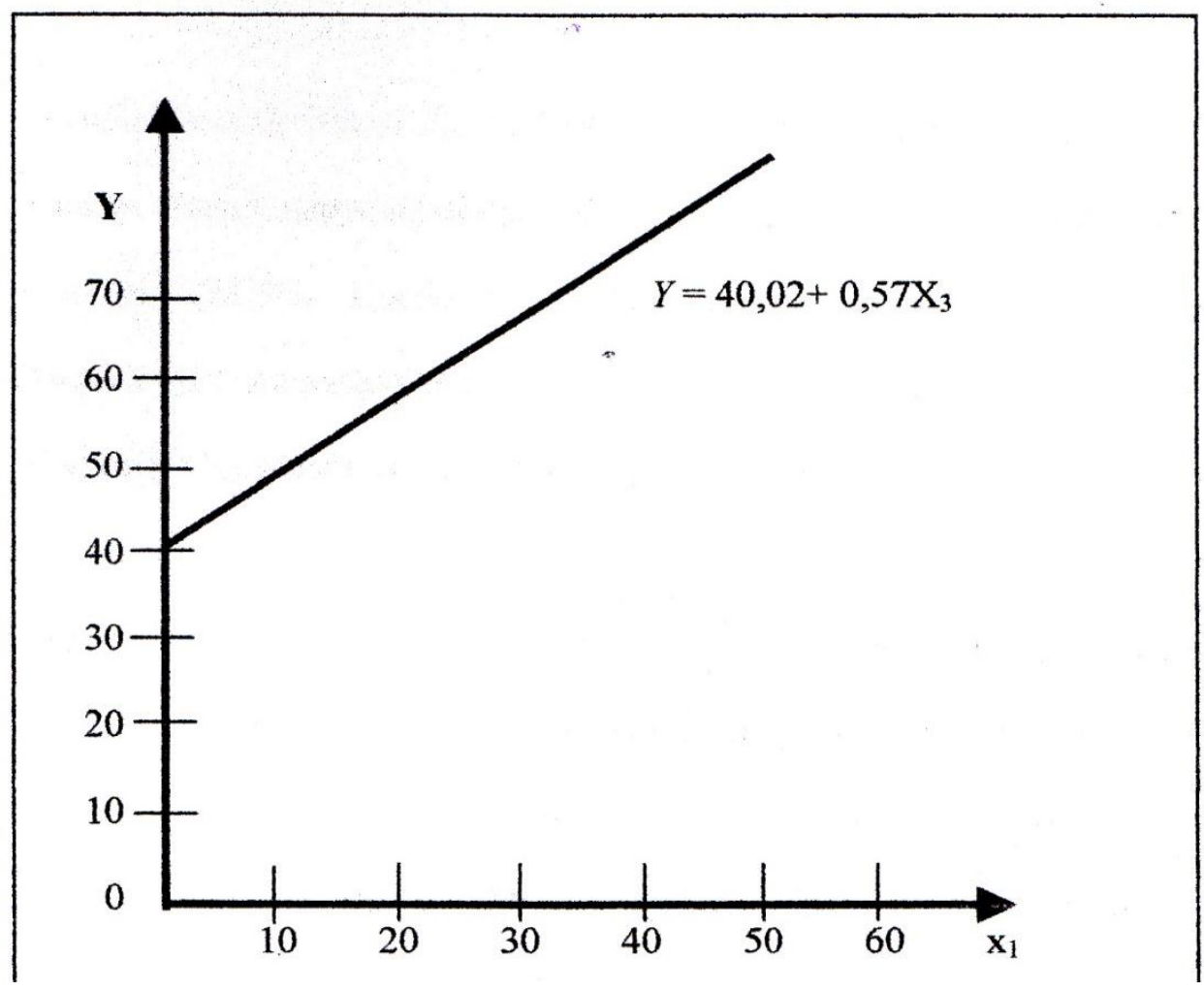

Table 6. List of $\mathbf{r}_{\mathrm{y} 3}$ Correlation Coefficient Significance Test

\begin{tabular}{|c|c|c|c|c|}
\hline \multirow{2}{*}{$\begin{array}{c}\text { Correlation } \\
\text { Coefficient }\end{array}$} & $\begin{array}{c}\text { Degree of } \\
\text { Freedom }\end{array}$ & \multirow{2}{*}{ F $_{\text {count }}$} & \multicolumn{2}{|c|}{ F $_{\text {table }}$} \\
\cline { 4 - 5 } & 48 & $7.772 * *$ & $\mathbf{0 . 0 5}$ & $\mathbf{0 . 0 1}$ \\
\hline 0.75 & 48 & 1.675 & 2.405 \\
\hline
\end{tabular}

$* *=$ The correlation coefficient is very significant $\left(\mathrm{t}_{\mathrm{count}}=8.594>\mathrm{t}_{\mathrm{table}}=2.405\right)$

Determinant coefficient $\mathrm{r}_{\mathrm{y} 3}^{2}=0.557$, means that variations in the writing scientific papers skills can be explained by variations in the ability to use cohesion devices by $55.7 \%$. Partial correlation coefficient $r_{\mathrm{y} 3.12}-0.43$, tested by $\mathrm{t}$-test, resulting in $\mathrm{t}_{\text {count }}=3.28>\mathrm{t}_{\text {table }}=$ $2.405 \alpha=0.01$ (significant). It means, the $\mathrm{X}_{1}$ variable is stably positive related to the $\mathrm{Y}$ variable.

Fourth, there is a positive relationship between the verbal reasoning ability $\left(\mathrm{X}_{1}\right)$, the word selection understanding $\left(\mathrm{X}_{2}\right)$, and the ability to use cohesion devices $\left(\mathrm{X}_{3}\right)$, together with the scientific writing papers skills $(\mathrm{Y})$, with a regression equation $Y=21.09+0.421 X_{1}+0,16$ $X_{2}+0,27 X_{3}$. The significance test for multiple regression can be seen in Table 7 . The 
regression equation model implies that if the verbal reasoning ability, the word selection understanding, and the ability to use cohesion devices, altogether are increased by one unit, there will be an increase in the value of writing scientific papers skills by 0.85 with a constant of 21.09 .

Table 7. Analysis of Variance (ANAVA) for Test of Meaning and Linearity of Regression of Writing Scientific Papers Skills (Y) on the verbal reasoning ability $\left(\mathrm{X}_{1}\right)$, the word selection understanding $\left(X_{2}\right)$, and the ability to use cohesion devices $\left(X_{3}\right)$.

\begin{tabular}{|l|c|r|r|r|r|r|}
\hline \multirow{2}{*}{ Varian Source } & \multirow{2}{*}{$\mathbf{d k}$} & \multirow{2}{*}{ JK } & \multirow{2}{*}{ RJK } & \multirow{2}{*}{$\mathbf{F}_{\text {count }}$} & \multicolumn{2}{|c|}{ F $_{\text {table }}$} \\
\cline { 6 - 8 } & & & & & $\boldsymbol{\alpha}=\mathbf{0 . 0 5}$ & $\boldsymbol{\alpha}=\mathbf{0 . 0 1}$ \\
\hline Regression & 3 & 3147.985 & 1049.319 & $39.411^{* *}$ & 2.81 & 4.24 \\
Rest & 46 & 1224.762 & 26.625 & - & - & - \\
\hline Total & 49 & 4392.720 & - & - & - & - \\
\hline
\end{tabular}

Information:

JK

$=$ Number of Squares

$\mathrm{dk}$

$=$ Degree of Freedom

RJK

$=$ Average Number of Squares,

$* *$

$=$ Linear regression $\left(\mathrm{F}_{\text {count }}=39.41>\mathrm{F}_{\text {table }}=4.24\right)$ on $\alpha$ level $=0.01$

The multiple correlation coefficient $\mathrm{R}_{\mathrm{y} 123}=0.85$ which turned out to be very significant using the F-test can be seen in Table 8. Coefficient of Determination $\mathrm{R}^{2}=0.72$, This means that $72 \%$ of the variation in the writing scientific papers skills can be explained by the verbal reasoning ability, the word selection ability, and the ability to use cohesion tools.

Table 8. List of test Coefficient Correlation $\mathbf{r}_{\mathbf{y} 123}$

\begin{tabular}{|c|c|c|c|c|}
\hline \multirow{2}{*}{$\begin{array}{c}\text { Coefficient } \\
\text { Correlation }\end{array}$} & $\begin{array}{c}\text { Degree of } \\
\text { Freedom }\end{array}$ & \multirow{2}{*}{$\mathbf{F}_{\text {count }}$} & \multicolumn{2}{|c|}{ F $_{\text {table }}$} \\
\cline { 4 - 5 } & 3,46 & $39,441^{* *}$ & $\mathbf{0 , 0 5}$ & $\mathbf{0 , 0 1}$ \\
\hline 0,85 & & 2,815 & 4,24 \\
\hline
\end{tabular}

$* *=$ Koefisien korelasi sangat signifikan $\left(t_{\text {hitung }}=39,441>t_{\text {tabel }}=4.24\right)$

Fifth, the relationship strength rank between the independent variable and the dependent variable can be discovered through the partial cohesion coefficient obtained by controlling other independent variables (see Table 9). 
Table 9. The Relationship Strength Rank of the Writing Scientific Papers Skills (Y) on the Reasoning Ability $\left(\mathbf{X}_{1}\right)$, the Word Selection Understanding $\left(\mathbf{X}_{2}\right)$, and the Ability to Use Cohesion Devices $\left(\mathbf{X}_{3}\right)$.

\begin{tabular}{|c|c|c|}
\hline Correlation & Degree of Correlation & Rank \\
\hline $\mathrm{r}_{\mathrm{y} 1.23}$ & 0.44 & First \\
\hline $\mathrm{r}_{\mathrm{y} 2.13}$ & 0.43 & Second \\
\hline $\mathrm{r}_{\mathrm{y} 3.12}$ & 0.26 & Third \\
\hline
\end{tabular}

Based on the table, it can be concluded that in relation to the skills of writing scientific papers, the relationship strength with the independent variable for the first rank is the ability of verbal reasoning, and for the second rank is the ability to use cohesion devices, and for the third rank is the understanding of word selection for the Jambi FEO.

\section{Conclusion}

The hypothesis test shows that all four hypotheses proposed in this research $(\mathrm{H} 1)$ are accepted, and the hypothesis (H0) is rejected. This can be interpreted that:

(1) There is a positive relationship between the ability of verbal reasoning and the skills in writing scientific papers.

(2) There is a positive relationship between the understanding of word selection and the skills in writing scientific papers.

(3) There is a positive relationship between the ability to use cohesion devices and the skills in writing scientific papers.

(4) There is a positive relationship between the ability of verbal reasoning, the understanding of word selection, and the ability to use cohesion devices, with the skills in writing scientific papers.

\section{Suggestions}

(1) In order to improve the FEO's skills in writing scientific papers, the Extension Center should postpone the task for writing scientific papers freely, and then a program to compose directed essays needs to be delivered.

(2) For the importance of the ability of verbal reasoning in order to improve the skills in writing, a verbal reasoning lesson needs to be reconsidered to be included in the training programs.

(3) Increasing the understanding of word selection and data is sought through a semantic training. Therefore it is suggested that in the learning implementation, there are 
efforts to improve the ability to use cohesion devices in the form of a Discourse Analysis training.

(4) The activity of Scientific Papers Writing Contest (SPWC), which is held periodically, and in stages from the Regency level to the Provincial, regional, and national, as a momentum to improve the FOE's skills in writing scientific papers.

(5) The Extension Center needs to publish magazines or journals whose function is to facilitate and distribute the activities and writing creativity of the FEO.

\section{BIBLIOGRAPHY}

Alwi, hasan ddk. Tata Bahasa baku Bahasa Indonesia, Edisi Kedua. Jakarta: balai Pustaka,1993.

Arnaudet, Martin L. dan mary Ellen Barret. Approaches to Academic Reading and Wraiting. Englewood Cliffs. New Jersey: Prentice-Hall,Inc., 1984.

Brotowidjoyo, Mukayat D. Penulisan Karang ilmiah. Jakarta: Akademika Presindo, 1988.

Brown, H. Douglas. Teaching by Principles: An Interactive Approach to Lengauge Pedalogy. Englewood Cliffs, New Jersey: Prentice-Hall Regents, 1994.

Calderonolle, Alice Heim dan Bruce L. Edwars, Jr.., Roughdrafis : The Process of Writing. Boston: Houghton Mifflin,1986.

Chapman, carmen. Authentic Writing Assessment, ERIC Digest. http://ericae.net/db/edo/ED328606.HTM.1999.

Cohesion: Using Repetition and Reference Words to Emphasize Key Ideas in your Writing. http://Ico. Stoloudstate. Edu/style/cohesion. Html.,1999.

Cook,Guy. Discourse. Oxford: Oxford University Press, 1989.

Copi, Irving M. Intoduction to Logic, Fifth Edition. New York: Macmillan Publishing Co., 1978.

D' Angelo, Frank J. Process and Thought in Compotition. Winthrop publisher, Inc., 1980.

Deductive and Inductive Thinking. 1999.http://trochim.human.cornel.edu/kb/DEDIND.htm.

Frank, Marcella. Writing as Thinking: A Guided Process Approach. Englewood Cliffs, New Jersey: Prentice-Hall,Inc., 190.

Garlikov, Richard. Resoning. http://www.educ.kent.edu/deafed/b990423.htm., 1999.

Gorrel, Robert M. dan Charton Laird. Modern English Handbook. Englewood Cliffs, New Jersey: Prentice-Hall,Inc., 1962.

Gutwinski, Weldemar. Cohesion in Literary Texts: A Study of some Grammatical and Lexical Features of English Discourse, the hague: Muouton, 1976.

Hariston, Maxine. Contemporary Compotion, Short Edition. Boston: Houghton Mifflin Company,1986.

Halliday, M.A.K. dan Ruqiya Hasan. Bahasa, konteks, dan teks: Aspek-aspek Bahasa dalam Pandangan Semiotik Sopsial, terjemahan Asrudin Barori Tou. Yogyakarta: Gadjah Mada University Press, 1992.

.Cohesion in English. London: Longman Group Ltd.,1976.

Heaton,J.B.Writing English Language Test. Longman Group Limited,1998. 
Heffernan,James A. W. dan john E. Lincoln, Writing : A College Handbook, Second Edition.New York:W.W.Norton and Company, Inc.,1986.

Karaf, Goys. Argumentasi dan Narasi. Jakarta: PT Gramedia,1992. .Diksi dan Gaya Bahasa. Ende Flores: Nusa Indah,1981.

Lawrence, Mary S. Writing as a Thinking Process. An Arbors: The University of Michigan Press, 1972.

Leahey, Thomas Hardi dan Richard Jakson Harris, Learning and Cognition, Fourth Edition. Upper Saddle River, New Jersey: Prentice-Hall, Inc.,1997.

Leonard, Henry S. Principles of Reasoning: An Inroduction to Logic, Methodology, and the Theory of Signs. New York: Dover Publication, Inc.,1967.

Levin, Gerals. The Macmillan Colege Handbook. New York: Macmillan Publishing Company, 1987.

McCarty, Michael. Discourse Analysis for Language Teachers. Cambridge: Cambridge Universyty Press, 1991.

McCimmon, James M.Writing with a purpose, Eight Edition. Boston: Houghton Mifflin Company, 1986.

Moelino, Anton M. Kembara Bahasa. Jakarta: Gramedia,1989.

Nunan, David. Introduching Discourese Analysis. Middlesex: Penguin,1993.

Pustcjovsky, James. Models of Lexical Meaning. http://www.cs.bradeis.edu/jamesp/models., 1999 .

Raimes, Ann. Techniques in Teaching Writing. Ozford: Oxford University Press, 1983.

Richard, Jack John Platt, dan Heidi Waber. Longman Dictionary of Applied Linguistics. England Longman, 1985.

Samsuri. Analisis Wacana. Malang penyelenggaraan Pendidikan Pascasarjana Proyek Peningkatan/ Pengembangan Perguruan Tinggi IKIP Malang. 1997.

Sarjiwi S. dan Joko Nurkamto. Analisis Kesalahan Pemakaian bahasa indonesia dalam Skripsi Mahasiswa:Sebuah Studi diprogram/Jurusan Non-Bahasa Indonesia Universitas Sekotamadia Surakarta, Surakarta: Laporan Penelitian DPPM, 1997.

Soekadijo, R.G.Logika Dasar: Tradisional,Simbolik,dan Indukatif. Jakarta:Kelompok 24 pengajaran Bahasa Indonesia,1991.

Sudiarto. Memantapkan Sistem Pendidikan Nasioanal, Jakarta: Gramedia Widiasarana Indonesia,1993.

Sudjiman, Panuti dan Dendy sugono. Petunjuk Penulisan Karya Ilmiah. Jakarta: Kelompok 24 Pengajaran Bahasa Indonesia, 1991.

Sugono, Dendy. Pelepasan Subjek dalam Bahasa Indonesia. Jakarta: Pusat Pembinaan dan Pengembangan Bahasa Departemen Pendidikan dan Kebudayaan,1995.

Suriasumantri,Jujun S. Filasafat Ilmu Sebuah Pengantar Populer. Jakatra: Sinar Harapan,1987.

White, Ron dan Valcric Arndt. Process Writing. London:Longman,1997. 